\title{
DRIVERS OF STUDENT ENTREPRENEURSHIP IN VISEGRAD FOUR COUNTRIES: GUESSS EVIDENCE
}

\section{Holienka, M., Gál, P., Kovačičová, Z.}

The aim of our paper is to find out what drives student entrepreneurs in Visegrad (V4) countries (i.e. the Czech Republic, Hungary, Poland, Slovakia) in their business activities. Our analysis is built on 2016 data from GUESSS project - an extensive academic study on student entrepreneurship, and our main sample comprises of 15,971 V4 university students. Potential drivers from individual human and social capital characteristics, perceived institutional support, and demographic attributes are examined, using the logistic regression method. Applying a unique perspective and distinguishing between different types of student entrepreneurs, we focus especially on promisingly sustainable student entrepreneurs with already active businesses, who plan to continue them after completing their studies. According to our results, gender (being a male), increasing age together with dropping number of years to finish studies, intensity of entrepreneurship education, studying in a business-related field, and having entrepreneurial parents significantly drive student entrepreneurship inclinations during their university studies.

Keywords: entrepreneurship; university students; drivers; GUESSS

JEL classification: L26

\section{Introduction}

Student entrepreneurship is an important phenomenon within the overall entrepreneurial dynamics. University students benefit from access to broad knowledge and networks, and enjoy freedom and opportunities for learning and experimenting that will rarely repeat after entering "real life" with all its duties and responsibilities. However, as in the general population, while some students get engaged in enterprising efforts, others remain distant. Providing that "more entrepreneurship" and "better entrepreneurship" is considered "good" for an economy and society as such, encouraging students to enter the entrepreneurial path is especially important. If they establish business activities already during their studies, the transition from student life to economically self-sufficient activity of an entrepreneur during their professional career is supposed to be much smoother. Also, individuals exploring an entrepreneurial career in the beginning of their economically active lives are more likely to follow such a direction also in the future. Thus, student entrepreneurship deserves considerable attention. Supporting student entrepreneurs can build on certain favorable preconditions. For example, students are exposed to educational and training programs, they can be easily targeted by support services and schemes, have unprecedented access to networks and knowledge, and can benefit from synergies based on interactions and interdisciplinarity. However, efficient support

An earlier version of this paper has been presented at the 5th International Conference Innovation Management, Entrepreneurship and Sustainability (IMES 2017) at the Faculty of Business Administration, University of Economics, Prague. 
of student entrepreneurship requires a good understanding of its nature (which is, as we will explain below, rather diverse) and its drivers.

Student entrepreneurs should not be considered as a homogeneous group. The reasons are twofold (as showed by GUESSS 2016 data): 1) a considerable part of them are still in a nascent stage without generating any revenues from their activity, and 2) even among the already active entrepreneurs, approximately half of them do not intend their current business activity to become their main occupation after completing university studies (for particular figures, refer to Table 1 below). Therefore, the presented paper narrows its focus to active and prospective student entrepreneurs only, and examines the drivers of their involvement in business.

The main research question of our paper is to find out the drivers of student involvement in active and prospective entrepreneurial efforts during their university studies, in comparison to abstaining from entrepreneurship.

\subsection{Student Entrepreneurship in the Context of Nowadays Universities}

The involvement of students in entrepreneurial efforts implied establishing the category of student entrepreneurs. According to Marchand and Hermens (2015), student entrepreneurs can be defined as individuals attending award classes at university and conducting innovative and revenue generating entrepreneurial activities. However, if we follow the broader understanding of entrepreneurship, this term can be expanded to cover all students involved in actively running any enterprising activities, i.e. acting upon identified opportunities and developed ideas, and transforming them into value for others. These entrepreneurial students take advantage of the various opportunities in the university environment such as specialized professors, spaces and support services (e.g. incubators), patent and copyright protections and advisory provided by the university, and, last but not least, their classroom learning (Mars et al., 2008). In addition, they might also use universities and their faculty members or students to validate and market products and services. Within this context, nowadays universities have moved far beyond providing only courses on entrepreneurship, as this seems to be not enough anymore. The role of universities in stimulating entrepreneurship has to be understood in a broader context. Therefore, entrepreneurship has become, besides educating students and conducting research, something like their third mandate (Jansen et al., 2015). With respect to students, according to Jansen et al. (2015), universities should encourage them through three groups of activities: stimulating (creating awareness of the entrepreneurial opportunities, presenting role models and success stories, etc.); educating (teaching the necessary skills, business plan creation, etc.); and incubating (various forms of support to start-up teams).

The nature of students' involvement in enterprising efforts is, however, rather diverse. As shown by some GUESSS national studies (e.g. Gubik and Farkas, 2016), a portion of students establishes enterprises with the main motive being to finance their studies and living expenses. Although students are formally engaged in different types of enterprises, they perform occasional activities (such as sales, financial advising, or artistic activities), or commission-based activities that are very similar to activities performed by employees, where the main difference usually is the flexible working hours enabling students to combine work with their study. Therefore, it is expected (and also empirically shown by GUESSS data, as we will explain in Table 1 below) that a considerable 
proportion of these types of student entrepreneurs would not continue in their businesses as in their main economic activity after the completion of university studies. In our paper, we try to eliminate these "quasi-employees" and "temporary part-time entrepreneurs", and we focus on prospective and active entrepreneurs who plan to keep the current entrepreneurial activity as their main occupation also after finishing their studies.

\subsection{Drivers of Involvement in Entrepreneurial Activity}

The potential drivers of entrepreneurial activity among university students shall correspond to the generally valid drivers, while also considering the specifics of student status and university environment. Therefore, we searched for the potential drivers within the following categories:

Individual human and social capital characteristics - within this category, participation in entrepreneurship education (as a human capital-related attribute) and having entrepreneurial parents (social capital-related attribute) shall be concerned as particularly relevant factors for the student population. First, intensity of entrepreneurship education shall contribute to an increase of entrepreneurship-relevant human capital, further reflected mainly in improving relevant skills and competencies, and ability to recognize and evaluate opportunities (Ramos-Rodríguez et al., 2010). Its positive effect on involvement in enterprising efforts has been suggested by several empirical studies (e.g. Menzies and Paradi, 2002; Charney and Libecap, 2000). Second, having entrepreneurial parents is a considerable component of an individual's social capital, as family is the closest and most important social group. In the Visegrad four context, we nowadays generally speak about the first generation which may already have parent entrepreneurs (Cieślik and van Stel, 2011). Several authors (e.g. Lindquist et al., 2015) argue that parental entrepreneurship considerably increases the likelihood of youth involvement in business activity, while the effect shall be contributed mainly to post-birth factors, especially parental role modelling and style (Sorensen, 2007; Blanchflower and Meyer, 1994). Also, thanks to mobilizing their social networks, such as family members, potential youth entrepreneurs are able to offset the lack of their human capital (Hulsink and Koek, 2014). Thus, we expect the increasing intensity of entrepreneurship education as well as having parent entrepreneurs to be positively related with student involvement in active and prospective entrepreneurial activity.

Perceived institutional support - as our specific focus are university students, we will concern the supportive nature of university environment, especially by considering perceived university's pro-entrepreneurial atmosphere, and perceived effects of provided (not only business-focused) education on development entrepreneurship-relevant attributes. Regarding the first, we expect the pro-entrepreneurial atmosphere to positively affect entrepreneurial inclination. As suggested by a study by Autio et al. (1997), the image of entrepreneurs and encouragement from university environment affect the entrepreneurial conviction of university students. Regarding the latter, increase in the skills and knowledge relevant to entrepreneurship resulting from educational process shall lead to increased entrepreneurial propensity, as belief in having skills, experience and knowledge has been broadly confirmed as significant drivers of youth early-stage business (e.g. Holienka et al., 2016a). According to a study by Turker and Selcuk (2009), if a university provides adequate knowledge and inspiration for entrepreneurship, the possibility of choosing an entrepreneurial career might increase among young people. Therefore, we 
suppose the university's pro-entrepreneurial atmosphere as well as effect of education on development of entrepreneurship-relevant attributes to be positively related to active and prospective student entrepreneurship.

Demographic attributes - within this category we consider generally established factors affecting involvement in entrepreneurship, such as gender and age, but we also expand our focus to attributes specific for university students, namely years to finish studies and field of study. First, as for gender, males generally exhibit higher entrepreneurial propensity within the overall population (Holienka et al., 2016b) as well as among the youth (e.g. Holienka et al., 2016a), being influenced by various gender-related attributes, such as opportunity perception and self-confidence to name a few (Langowitz and Minniti, 2007). Second, increase in age is generally linked with accumulation of human and social capital (e.g. Minola et al., 2014), factors that positively influence tendency to start business activities. Empirical findings suggest that among the young population, involvement in entrepreneurship increases with age (Lukes and Zouhar, 2013; Amorós and Bosma, 2014), so the similar pattern should be expected within student population. Third, regarding the number of years to finish university, increased interest in entering the economically active life would be expected with approaching the end of studies. As one of the options is self-employment through starting one's own business, increased involvement of students closer to completing their studies shall be expected, compared to their more recently enrolled counterparts. Fourth, as far as the field of study is concerned in relation to entrepreneurial activity, higher involvement of business students would be expected due to generally expected higher intensity of entrepreneurial education resulting to increased skills, knowledge and related self-efficacy (Von Graevenitz et al., 2010), as well as due to study field selection bias, where students interested in entrepreneurship are supposed to have increased interest in business education. On the other hand, non-business students often have an advantage based on being equipped with certain marketable professional domain or skill (e.g. informatics, engineering, design etc.), unlike business students, which gives them a good basis to turn these assets into viable business. Different levels of particular entrepreneurial characteristics among university students across the fields of study have been identified by empirical research (Holienka et al., 2015). To sum up, we expect gender (male), increasing age, proximity to finishing studies and enrollment in business-related field of study to be positively related to active and prospective student entrepreneurship.

\section{Methods}

Our analysis was based on 2016 Global University Entrepreneurial Spirit Students' Survey (GUESSS) data for Visegrad countries - the Czech Republic, Hungary, Poland and Slovakia. GUESSS is a worldwide survey on entrepreneurial attitudes, plans, activities and aspirations of university students, collecting primary data through its own survey instrument. The 2016 overall sample is comprised of $122,000+$ university students from 50 countries worldwide. The data was gathered using an online questionnaire following the convenience sampling approach, with being an active higher education student as the only selection criteria. In accordance with the aim of our analysis, we geographically limited the sample to V4 countries, resulting into the main research sample consisting of total 15,971 individuals. Prior to the main investigation, we conducted a descriptive 
analysis of involvement in entrepreneurship among university students in Visegrad countries. Then, the main part of our analysis was aimed at investigating the potential drivers of student entrepreneurship. Our dependent variable indicates involvement in active and prospective enterprise $(1=$ already running own business or being self-employed, and planning that business to become the main occupation after graduation; $0=$ not running or trying to start own business, not self-employed or trying to become self-employed). Our main research sample contained 436 active and prospective entrepreneurs $(2.73 \%)$ and $11,712(73.3 \%)$ non-entrepreneurs.

The explanatory variables included in our analysis can be grouped into three categories.

- First, demographic attributes included gender $(0=$ female, $1=$ male $)$, age, years to finish studies $(0,1,2,3$ and more years), and field of study (business=1, non-business=0).

- Second, individual human and social capital characteristics included entrepreneurship education intensity ( $1=$ no course, $2=$ voluntary course, $3=$ obligatory course, $4=$ special program $)$, and having parent entrepreneurs $(0=$ none, $1=$ one of parents, $2=$ both parents).

- Third, variables assessing the perceived institutional support included university pro-entrepreneurial atmosphere (3-items, 1-7 Likert-type scale), and perceived effect of received education on entrepreneurial qualities (5-items, 1-7 Likert-type scale).

Furthermore, we included the country dummy to control for country differences.

To examine the influence of the analyzed variables on our dependent variable we employed a binomial logistic regression analysis. We have estimated a set of logistic regressions with a binomial dependent variable - odds of being involved in active and prospective entrepreneurship. To estimate the parameters of the models, we used IBM SPSS Statistics 24 software. The significance of parameters was tested using Wald z-statistics. Maximum likelihood estimations were used to calculate the logit coefficients denoting changes in the log odds of the dependent variable.

\section{Results and Discussion}

The results of a descriptive analysis of student involvement in entrepreneurial endeavors are presented in Table 1.

As can be seen from the results presented in Table 1, a considerable proportion of the Visegrad four university student population (from $17.7 \%$ in Slovakia to $33.9 \%$ in Poland) interviewed in the GUESSS project had been involved in some type of entrepreneurial activity. A closer look at this structure, however, unveils that the majority of this activity had been in its nascent stage (especially in samples from Hungary and Poland). Moreover, a clear majority of these nascent student entrepreneurs had not generated any revenues from their business activities yet. On the contrary, the share of already active entrepreneurs among the student population involved in entrepreneurship varied among the country samples (from $11.3 \%$ in Poland to $42.9 \%$ in Czech Republic). Despite the variance in this proportion, the share of those active entrepreneurs planning to continue in their businesses after completion of their studies (i.e. prospective entrepreneurs) was rather similar - between 40 to $60 \%$ of active student entrepreneurs. These results confirm 
that student entrepreneurs shall not be considered as a homogeneous group, and thus advocates for our approach to focus the analysis on a particular type of student entrepreneurs - those involved in active and prospective entrepreneurship.

The results of binomial logistic regression conducted to identify factors influencing students' involvement in active and prospective entrepreneurial activity are presented in Table 2.

Table 1 | Student entrepreneurship in Visegrad countries (descriptive analysis results)

\begin{tabular}{|l|c|c|c|c|}
\hline & Hungary & Poland & $\begin{array}{c}\text { Czech } \\
\text { Republic }\end{array}$ & Slovakia \\
\hline $\begin{array}{l}\text { Involvement in entrepreneurship } \\
\text { (any type), \% of student pop. }\end{array}$ & $24.0 \%$ & $33.9 \%$ & $23.6 \%$ & $17.7 \%$ \\
\hline Out of that: nascent & $76.7 \%$ & $88.7 \%$ & $57.1 \%$ & $61.0 \%$ \\
\hline Out of that: nascent, no sales yet & $70.4 \%$ & $80.1 \%$ & $44.8 \%$ & $50.4 \%$ \\
\hline Out of that: active & $23.3 \%$ & $11.3 \%$ & $42.9 \%$ & $39.0 \%$ \\
\hline $\begin{array}{l}\text { Out of that: active, no intention to } \\
\text { continue after studies }\end{array}$ & $13.3 \%$ & $5.2 \%$ & $20.5 \%$ & $15.9 \%$ \\
\hline $\begin{array}{l}\text { Out of that: active and prospective } \\
\text { entrepreneurs }\end{array}$ & $9.7 \%$ & $6.1 \%$ & $19.4 \%$ & $22.6 \%$ \\
\hline
\end{tabular}

Source: Own calculations based on GUESSS data

As can be seen from Table 2, six explanatory variables proved significance in relation to students' involvement in active and prospective entrepreneurship. The highest explanatory power was observed in the case of gender, where being a male increases the odds of being an entrepreneur by more than three times. The second highest explanatory power was observed in the case of having entrepreneurial parents, where an increase in parents' involvement intensity (i.e. one vs. none, both vs. only one) doubles the odds of active and prospective involvement in business. The odds of becoming an active and prospective entrepreneur also increase with increasing intensity of entrepreneurship education, as well as with age of an individual. The first model also estimated the significance of number of years to finish studies (with slightly increasing odds of involvement in business with approaching end of the studies), as well as the field of study (with higher odds for business students) (in the remaining two models, these variables were still significant at 0.1 interval). As for country variable, compared to base category (i.e. Slovakia), odds of involvement in active and prospective business are significantly lower for Hungarian and Polish students, while Czech students show no significant difference.

Our findings suggest that gender, a characteristic that works well as a driver of business activity in general for youth populations (e.g. Holienka et al., 2016a), was found to be significant also within the population of V4 university students. It seems that university environment does not eliminate the gender bias of entrepreneurial activity. Thus, universities are not helping to improve the overall insufficient inclusivity of females in 
entrepreneurship typical for our region (e.g. Pilkova et al., 2016). Therefore, specific initiatives have to be developed and implemented to encourage and support more female students in their entrepreneurial activities.

Table 2 | Active and prospective entrepreneurship drivers (logistic regression results)

\begin{tabular}{|c|c|c|c|c|c|c|}
\hline & \multicolumn{2}{|c|}{ Mod 1} & \multicolumn{2}{|c|}{ Mod 2} & \multicolumn{2}{|c|}{ Mod 3} \\
\hline Variable & $\begin{array}{c}\text { B } \\
(\mathrm{S} . \mathrm{E} .)\end{array}$ & OR & $\begin{array}{c}\text { B } \\
\text { (S.E.) }\end{array}$ & OR & $\begin{array}{c}\text { B } \\
\text { (S.E.) }\end{array}$ & OR \\
\hline Constant & $\begin{array}{c}-4.731^{* * *} \\
(.193)\end{array}$ & .009 & $\begin{array}{c}-8.543^{* * *} \\
(.371)\end{array}$ & .000 & $\begin{array}{c}-8.440^{* * *} \\
(.384)\end{array}$ & .000 \\
\hline Gender & $\begin{array}{c}1.132 * * * \\
(.107)\end{array}$ & 3.103 & $\begin{array}{l}1.141^{* * *} \\
(.111)\end{array}$ & 3.131 & $\begin{array}{l}1.149 * * * \\
(.113)\end{array}$ & 3.154 \\
\hline Age & $\begin{array}{l}.949 * * * \\
(.070)\end{array}$ & 2.583 & $\begin{array}{l}.175^{* * *} \\
(.011)\end{array}$ & 1.91 & $\begin{array}{l}.177^{* * *} \\
(.011)\end{array}$ & 1.193 \\
\hline Years to finish & $\begin{array}{l}-.123^{* *} \\
(.052)\end{array}$ & .885 & $\begin{array}{l}-.092^{*} \\
(.054)\end{array}$ & .912 & $\begin{array}{l}-.097^{*} \\
(.055)\end{array}$ & .908 \\
\hline Field of study & $\begin{array}{l}.435^{* * *} \\
(.108)\end{array}$ & 1.545 & $\begin{array}{l}.206^{*} \\
(.121)\end{array}$ & 1.228 & $\begin{array}{l}.226^{*} \\
(.124)\end{array}$ & 1.254 \\
\hline EE intensity & & & $\begin{array}{l}.237^{* * *} \\
(.056)\end{array}$ & 1.268 & $\begin{array}{l}.241^{* * *} \\
(.058)\end{array}$ & 1.273 \\
\hline $\begin{array}{l}\text { Parents } \\
\text { entrepreneurs }\end{array}$ & & & $\begin{array}{l}.765^{* * *} \\
(.071)\end{array}$ & 2.149 & $\begin{array}{l}.751^{* * *} \\
(.072)\end{array}$ & 2.120 \\
\hline $\begin{array}{l}\text { University } \\
\text { atmosphere }\end{array}$ & & & & & $\begin{array}{l}.010 \\
(.053)\end{array}$ & 1.010 \\
\hline EE effects & & & & & $\begin{array}{l}-.048 \\
(.056)\end{array}$ & .953 \\
\hline \multicolumn{7}{|l|}{ Slovakia } \\
\hline Hungary & $\begin{array}{c}-.931^{* * *} \\
(.140)\end{array}$ & .394 & $\begin{array}{c}-.975^{* * *} \\
(.147)\end{array}$ & .377 & $\begin{array}{l}-.981^{* * *} \\
(.149)\end{array}$ & .375 \\
\hline Poland & $\begin{array}{c}-.629 * * * \\
(.136)\end{array}$ & .533 & $\begin{array}{c}-.723^{* * *} \\
(.144)\end{array}$ & .485 & $\begin{array}{c}-.719 * * * \\
(.147)\end{array}$ & .487 \\
\hline Czech Republic & $\begin{array}{l}-.174 \\
(.182)\end{array}$ & .840 & $\begin{array}{l}-.158 \\
(.190)\end{array}$ & .854 & $\begin{array}{l}-.135 \\
(.193)\end{array}$ & .874 \\
\hline Observations & 11265 & & 11096 & & 10879 & \\
\hline $\mathbf{R}^{2}$ & .122 & & .170 & & .170 & \\
\hline -2 Log likelihood & 3069.544 & & 2807.777 & & 2745.003 & \\
\hline
\end{tabular}

Source: Own calculations based on GUESSS data 
As for age and years to finish study, both attributes indicate individual maturity and proximity to real life after completion of studies. There one has to become economically active, with one of the options being economic self-sufficiency via entrepreneurship. As students get older or come closer to graduation, they start their professional careers and part of them enter the entrepreneurial path. Thus, proximity of real life might be the triggering event for those who have been considering entrepreneurship, but have not taken any concrete steps yet.

Our findings also indicate that besides generally valid drivers, universities' effect on entrepreneurship-relevant individual human capital plays also a significant role. Increased intensity of entrepreneurial education together with attending business-related field of study are associated with increased involvement of students in entrepreneurial activities. However, understanding the causality of this relation would require further investigation. In fact, both directions would make sense - students can either do business because they were taught and motivated to do so, or they might have selected business studies due to interest in doing business, that also lead them to start one alongside their studies.

Having entrepreneurial parents, being a generally well-established driver, works also in the V4 student population. Also, intensity of family involvement matters, as odds increase with both parents involved in entrepreneurship. We may argue that parental role models positively affect entrepreneurial appetite in two possible ways - through providing positive attitude, and through enabling to naturally gather business-relevant skills. However, absence of entrepreneurial family background implies limited social and professional mobility. Thus, effective mechanisms should be developed to (partially) replace the positive effect of parents-entrepreneurs among students from non-entrepreneur families.

To our surprise, we did not find any significance in the relationship between perceived institutional support (i.e. university atmosphere and perceived effect of received education on entrepreneurial qualities) and students' involvement in active and prospective business. Thus, it seems that a supportive environment itself is not a sufficient driver. Besides creating a favorable entrepreneurial climate, key attention should be aimed at individual-level actions.

Our analysis also identified significance when controlling for country effects. Students in Poland and Hungary show lower odds of active and prospective entrepreneurship compared to Slovakia (reference category). This pattern originates in their lower inclusion in active entrepreneurship and lower percentage of entrepreneurs expecting business lifespan exceeding the university studies. Separate country models that were estimated, however, showed great similarity in terms of drivers (both in their strength and structure) among V4 countries.

\section{Conclusion}

To conclude, our analysis of drivers related to students' involvement in active and prospective entrepreneurship during their university studies unveiled that while university influence certainly matters, general drivers work to a great extent for student populations. Effects of the university environment and entrepreneurship focus, however, seem to not be able to break the traditional influence of well-established factors. Also, we observed that students became more decided to take the concrete action and start a business as they 
approach the end of their studies. Therefore, in our opinion, universities should capitalize upon the existing general effects, but at the same time they need to target problematic issues (such as the gender gap or business family gap) and develop actions to solve them through well-established instruments (e.g. intensity of entrepreneurial education) focused and tailored to particular target groups.

\section{References}

Amorós, J. E., \& Bosma, N. (2014). Global Entrepreneurship Monitor 2013: Global Report. London: GERA.

Autio, E., et al. (1997). Entrepreneurial intent among students: testing an intent model in Asia, Scandinavia and USA. Frontiers of Entrepreneurship Research, Babson Conference Proceedings. Babson College.

Blanchflower, D. G., \& Meyer, B. (1994). A longitudinal analysis of the young self-employed in Australia and the United States. Small Business Economics, 6, 1-20.

Cieślik, J., \& van Stel, A. (2011). Trends in Entrepreneurial Activity in Central and East European Transition Economies. In: Economic Development and Entrepreneurship in Transition Economies (pp. 701-720). Banja Luka: University of Banja Luka.

Holienka, M., Holienkova, J., \& Gal, P. (2015). Entrepreneurial Characteristics of Students in Different Fields of Study: a View from Entrepreneurship Education Perspective. Acta Universitatis Agriculturae et Silviculturae Mendelianae Brunensis, 63(6), 1879-1889.

Holienka, M., Pilkova, A., \& Jancovicova, Z. (2016a). Youth Entrepreneurship in Visegrad Countries. Entrepreneurial Business and Economics Review, 4(4), 105-121.

Holienka, M., Jancovicova, Z., \& Kovacicova, Z. (2016b). Women entrepreneurship in Visegrad region and its drivers. Acta Universitatis Agriculturae et Silviculturae Mendelianae Brunensis, 64(6), 1899-1910.

Hulsink, W., \& Koek, D. (2014). The young, the fast and the furious: a study about the triggers and impediments of youth entrepreneurship. International Journal of Entrepreneurship and Innovation Management, 18(2-3), 182-209.

Charney, A., \& Libecap, G. D. (2000). The Impact of Entrepreneurship Education: An Evaluation of the Berger Entrepreneurship Program at the University of Arizona, 1985-1999. Kansas City: The Kauffman Center for Entrepreneurial Leadership.

Jansen, S., et al. (2015). How education, stimulation, and incubation encourage student entrepreneurship: Observations from MIT, IIIT, and Utrecht University. The International Journal of Management Education, 13(2), 170-181.

Langowitz, N., \& Minniti, M. (2007). The entrepreneurial propensity of women. Entrepreneurship theory and practice, 31(3), 341-364.

Lindquist, M., Sol., J., \& van Praag, M. (2015). Why Do Entrepreneurial Parents Have Entrepreneurial Children? Journal of Labor Economics, 33(2), 269-296.

Lukes, M., \& Zouhar, J. (2013). No experience? No problem - it's all about yourself: Factors influencing nascent entrepreneurship outcomes. Ekonomicky casopis, 61(9), 934-950.

Marchand, J., \& Hermens, A. (2015). Student Entrepreneurship: A Research Agenda. International Journal of Organizational Innovation, 8(2), 266-282.

Mars, M. M., Slaughter, S., \& Rhoades, G. (2008). The State-Sponsored Student Entrepreneur. The Journal of Higher Education, 79(6), 638-670. 
Menzies, T. V., \& Paradi, J. C. (2002). Encouraging technology-based ventures: Entrepreneurship education and engineering graduates. New England Journal of Entrepreneurship, 5(2), 57-64.

Minola, T., Criaco, G., \& Cassia, L. (2014). Are youth really different? New beliefs for old practices in entrepreneurship. International Journal of Entrepreneurship and Innovation Management, 18(2/3), 233-259.

Pilkova, A., Holienka, M., Kovacicova, Z., \& Rehak, J. (2016). Komercne, socialne a inkluzivne podnikanie na Slovensku. Bratislava: Univerzita Komenskeho v Bratislave.

Ramos-Rodríguez, A. R. et al. (2010). What you know or who you know? The role of intellectual and social capital in opportunity recognition. International Small Business Journal, 28(6), 566-582.

Sørensen, J. B. (2007). Closure and exposure: Mechanisms in the intergenerational transmission of self-employment. Research in the Sociology of Organizations, 25(83), 83-124.

Turker, D., \& Selcuk, S. S. (2009). Which factors affect entrepreneurial intention of university students? Journal of European Industrial Training, 33(2), 142-159.

Von Graevenitz, G., Harhoff, D., \& Weber, R. (2010). The effects of entrepreneurship education. Journal of Economic Behavior \& Organization, 76, 90-112.

\section{Authors}

Mgr. Marian Holienka, PhD.

Comenius University in Bratislava

Faculty of Management, Department of Strategy and Entrepreneurship

Odbojarov 10, P.O. Box 95, 82005

Bratislava, Slovakia

marian.holienka@fm.uniba.sk

\section{Mgr. Peter Gál, PhD.}

Comenius University in Bratislava

Faculty of Management, Department of Strategy and Entrepreneurship

Odbojarov 10, P.O. Box 95, 82005

Bratislava, Slovakia

peter.gal@fm.uniba.sk

RNDr. Zuzana Kovačičová, PhD.

Comenius University in Bratislava

Faculty of Management, Department of Information Systems

Odbojarov 10, P.O. Box 95, 82005

Bratislava, Slovakia

zuzana.kovacicova@fm.uniba.sk

This paper is based on data from Global University Entrepreneurial Spirit Students' Survey - GUESSS. Comenius University in Bratislava, Faculty of Management is the national GUESSS coordinator in Slovakia.

This work was supported by the Slovak Research and Development Agency under the contract No. APVV-14-0647. 